\title{
Augmented Expression of Atrial Natriuretic Polypeptide Gene in Ventricle of Human Failing Heart
}

Yoshihiko Saito," Kazuwa Nakao, * Hiroshi Arai, " Kazunobu Nishimura," Ken Okumura," Kenji Obata," Genzou Takemura," Hisayoshi Fujiwara," Akira Sugawara," Takayuki Yamada," Hiroshi Itoh," Masashi Mukoyama," Kiminori Hosoda," Chuichi Kawai," Toshihiko Ban," Hirofumi Yasue," and Hiroo Imura*

*Second Division, Department of Medicine, ${ }^{\ddagger}$ Department of Cardiovascular Surgery, "Third Division, Department of Medicine, Kyoto University School of Medicine Kyoto 606, Japan; ${ }^{\S}$ Department of Cardiology, Kumamoto University School of Medicine Kumamoto 860, Japan

\section{Abstract}

To elucidate the expression of the atrial natriuretic polypeptide (ANP) gene in the ventricle of the human failing heart, we have measured ANP and ANP messenger RNA (ANPmRNA) levels in left ventricular aneurysm obtained at operation, biopsy specimens of left ventricles from dilated cardiomyopathy (DCM) and autopsy samples of old myocardial infarction (OMI) and DCM hearts, and compared the levels with those in the normal ventricle. The ANP level (mean \pm SE) was 17.5 \pm 6.9 $\mathrm{ng} / \mathrm{g}$ in the normal ventricle, and increased to $660.3 \pm 122.2$ $\mathrm{ng} / \mathrm{g}$ in the left ventricular aneurysm tissues and to $3,138.6 \pm 1,642.1 \mathrm{ng} / \mathrm{g}$ in the biopsy specimens of the DCM ventricle. These levels were $\sim \mathbf{4 0}$ and $\mathbf{2 0 0}$ times higher than in the normal ventricle. The increase of ANP levels was observed in both infarcted and noninfarcted regions of the OMI heart, and in the entire ventricle of the DCM heart. A significant positive correlation was found between the ANP level in aneurysm tissues and pulmonary capillary wedge pressure ( $r$ $=0.85)$. The ANPmRNA level in the left ventricular aneurysm showed about a 10-fold increase compared with that in the normal heart and reached $23 \%$ of that in the atrium of the same heart. A similar increase in the ANPmRNA level was observed in the entire ventricle of DCM. These data clearly indicate that the expression of the ANP gene in the ventricle is augmented in the failing heart in accordance with the severity of heart failure. In the atrium of the failing heart, ANP and ANPmRNA levels were only two times higher than those in the normal atrium. Thus, the augmentation in the expression of the ANP gene was more prominent in the ventricle than in the atrium. Taking tissue weight into account, the total content of ANPmRNA in the ventricle of the failing heart is much the same as that in the normal atrium. The ratio of the ANP level to the ANPmRNA level in the ventricle is much smaller than that in the atrium. These results suggest more rapid secretion of ANP after synthesis in the ventricle.

These findings demonstrate that the expression of the ANP gene is augmented in the human ventricle of the failing heart and suggest that the ventricle becomes a substantial source of circulating ANP in congestive heart failure.

Address reprint requests to Dr. Nakao, Second Division, Department of Medicine, Kyoto University School of Medicine, 54 Shogoin Kawahara-cho, Sakyo-ku, Kyoto 606, Japan. 1988.

Received for publication 13 May 1987 and in revised form 12 July

J. Clin. Invest.

(c) The American Society for Clinical Investigation, Inc.

0021-9738/89/01/0298/08 \$2.00

Volume 83, January 1989, 298-305

\section{Introduction}

Atrial natriuretic polypeptide (ANP) ${ }^{1}$ is a cardiac hormone secreted through the coronary sinus from the heart and is involved in fluid, electrolyte, and vascular homeostasis (1-7). The plasma ANP concentration is increased in patients with congestive heart failure (CHF) in relation to its severity (8-10), and this elevation of the plasma ANP concentration is mainly due to increased secretion of ANP from the heart $(7,11)$. It is of great importance, therefore, to investigate ANP synthesis in the human failing heart in order to elucidate the clinical implication of ANP in CHF. We have recently reported that ANP synthesis is augmented in the atrium in accordance with the severity of CHF (12). Since ANP was first discovered from atrial tissues, the atrium had been thought to be the sole source of circulating ANP (4, 13-16). There is growing evidence, however, indicating that ANP is also synthesized in the ventricle of normal animals (17-19) and that ANP synthesis in the ventricle is increased under certain pathological conditions, such as spontaneously hypertensive rats (SHR) $(20,21)$, SHR stroke-prone (20), cardiomyopathic hamsters (22), experimentally volume or pressure overloaded rats (23-25), and myocarditis mice (26). In evaluating ANP synthesis in the human failing heart, it is, therefore, necessary to investigate ANP synthesis not only in the atrium but also in the ventricle. To date, however, there has been only a few preliminary reports on human ventricular ANP. We reported that the ANP gene is expressed in the normal ventricle as well as in the atrium and that the expression is augmented in the ventricle in a patient with dilated cardiomyopathy (DCM) (27). Immunohistochemical studies performed by us and others have also confirmed the increased ANP immunostaining in diseased ventricular cardiocytes $(28,29)$.

Specimens obtained at operation and biopsy have a great advantage for the precise analysis of ANP and ANPmRNA levels, because of minimal postmortem nonspecific degradation. On the other hand, the autopsy sample is useful to evaluate ANP synthesis in the whole heart. To further elucidate ANP synthesis in the ventricle of the human failing heart, we investigated in the present study ANPmRNA and ANP in ventricles of old myocardial infarction (OMI) and DCM hearts, using samples obtained at operation, biopsy, and autopsy.

1. Abbreviations used in this paper: ANP, atrial natriuretic polypeptide; CAD, coronary artery disease; $\mathrm{CHF}$, congestive heart failure; DCM, dilated cardiomyopathy; OMI, old myocardial infarction; PCWP, pulmonary capillary wedge pressure; SHR, spontaneously hypertensive rats. 


\section{Methods}

Patients. Hearts from 14 patients with $\mathrm{CHF}$ and 10 patients without $\mathrm{CHF}$ were investigated in this study. There were 18 men and 6 women, ranging in age from 40 to $76 \mathrm{yr}$ with a mean $\pm S E$ of $62.1 \pm 1.8 \mathrm{yr}$. The cause of CHF was antero-septal OMI in eight patients, inferior OMI in one, and DCM in five. In six of the eight patients with antero-septal OMI, left ventricular aneurysmectomy was carried out because of refractory CHF or life-threatening arrhythmia. Severity of CHF and hemodynamic data at the time of operation are summarized in Table I. Four of the five patients with DCM underwent the diagnostic catheterization and left ventricular biopsy. Clinical characteristics in these four patients are summarized in Table II. In the remaining four patients (two patients with antero-septal OMI, each one patient with inferior OMI or DCM), hearts were excised within 3-14 h after death at autopsy. Cause of death was pump failure in three and arrhythmia in one (patient 3).

10 patients without $\mathrm{CHF}$ consisted of 5 patients with coronary artery disease (CAD) and 5 autopsied patients without cardiac complications. The cardiac catheterization showed normal left and right ventricular functions with normal pulmonary capillary wedge pressure (PCWP) and right atrial pressure in five patients with CAD. They underwent aorto-coronary bypass surgery. The causes of death in five patients without cardiac complications are listed in Table III. None of the 10 patients showed clinical signs or symptoms of CHF. Systolic and diastolic blood pressures were within normal ranges in these 10 patients. Informed consent was obtained from each patient or family. This study was approved by the ethical committee on human research of Kyoto University (No. 61-9).

Tissue preparation (samples obtained at operation and at biopsy). Left ventricular tissues obtained at operation for aneurysmectomy were separated into epicardial and endocardial halves except for the transmurally scarred region and were cut into several blocks in parallel to the longitudinal axis (Fig. 2). Small specimens (2-4 mg) were obtained at biopsy from the subendocardium of left ventricular free wall using biotorm (Machida Tokyo, Japan) in four patients with DCM. Atrial tissues were also obtained from the apical portion of the right auricle in six patients with left ventricular aneurysm and in five patients with $C A D$, when the venous cannula was inserted into the right auricle for the extracorporal circulation. Blocks were immediately frozen in liquid nitrogen and stored at $-70^{\circ} \mathrm{C}$ until extraction.

Table I. Pertinent Clinical and Hemodynamic Data and Plasma and Tissue ANP Levels in Patients with LV Aneurysm

\begin{tabular}{|c|c|c|c|c|c|c|c|c|c|}
\hline \multirow[b]{3}{*}{ Patient } & \multirow[b]{3}{*}{ Age } & \multirow[b]{3}{*}{ Sex } & \multirow[b]{3}{*}{$\begin{array}{c}\text { NYHA } \\
\text { class }\end{array}$} & \multirow[b]{3}{*}{ PCWP } & \multirow[b]{3}{*}{ RAP } & \multirow{3}{*}{$\begin{array}{c}\text { Plasma } \\
\text { ANP } \\
\text { level }\end{array}$} & \multicolumn{3}{|c|}{ Tissue ANP level } \\
\hline & & & & & & & \multicolumn{3}{|c|}{$\begin{array}{c}\text { LV aneurysm } \\
(n g / g)\end{array}$} \\
\hline & & & & & & & ARAu & Mean & $\operatorname{Max}$ \\
\hline & & & & $m m H g$ & $m m H g$ & $p g / m l$ & $\mu g / g$ & & \\
\hline 1 & 58 & $\mathbf{M}$ & II & 8 & 3 & 68.7 & 24.0 & 366.7 & 831.6 \\
\hline 2 & 62 & $\mathbf{F}$ & II & 12 & 4 & 287.5 & 24.7 & 460.8 & 992.2 \\
\hline 3 & 53 & $\mathbf{M}$ & III & 18 & 4 & 576.8 & 30.1 & 475.2 & $1,261.7$ \\
\hline 4 & 70 & $\mathbf{M}$ & III & 20 & 4 & 164.0 & 54.9 & 789.0 & $1,735.8$ \\
\hline 5 & 67 & $\mathbf{M}$ & III & 18 & 2 & 720.4 & 99.1 & $1,180.5$ & $2,098.4$ \\
\hline 6 & 58 & $\mathbf{F}$ & IV & 20 & 4 & $1,281.3$ & 101.8 & 918.0 & $2,349.9$ \\
\hline Mean & 61.3 & & & 16.2 & 3.5 & 516.5 & 55.8 & 660.3 & $1,544.9$ \\
\hline$\pm \mathrm{SE}$ & \pm 2.6 & & & \pm 2.0 & \pm 0.3 & \pm 183.2 & \pm 14.9 & \pm 122.2 & \pm 250.7 \\
\hline
\end{tabular}

ANP, atrial natriuretic polypeptide; LV, left ventricle; NYHA, New York Heart Association; PCWP, pulmonary capillary wedge pressure; RAP, right atrial pressure; ARAu, apical portion of right auricle; Mean, the mean ANP level in each aneurysm tissue; Max, the maximal value of the ANP level in each aneurysm tissue.
Table II. Tissue ANP Concentrations in Biopsy Specimens from DCM Hearts

\begin{tabular}{cccccr}
\hline Patient & Age & Sex & PCWP & $\begin{array}{c}\text { Plasma ANP } \\
\text { level }\end{array}$ & $\begin{array}{c}\text { Tissue ANP } \\
\text { level }\end{array}$ \\
\hline & & & $m m H g$ & $p g / m l$ & $n g / g$ \\
1 & 54 & M & 7 & 69 & $1,536.3$ \\
2 & 61 & F & 9 & 135 & 963.3 \\
3 & 57 & M & 11 & 199 & $6,916.3$ \\
4 & 62 & M & 20 & 267 & $1,289.6$ \\
Mean & 46.3 & & 11.8 & 167.5 & $3,138.6$ \\
\pm SE & \pm 13.8 & & \pm 2.9 & \pm 42.5 & $\pm 1,642.1$
\end{tabular}

Tissue preparation (autopsy samples). Hearts excised from patients without cardiac complications weighed from 250 to $350 \mathrm{~g}(299 \pm 26 \mathrm{~g})$ and the ventricular wall thickness was $11.7 \pm 1.5 \mathrm{~mm}$ in the left and $2.3 \pm 0.3 \mathrm{~mm}$ in the right. No pathological findings were observed macroscopically or microscopically. In the failing heart, the weight was significantly increased to $480 \pm 40 \mathrm{~g}$. Ventricular hypertrophy was also evident by increases in the left and right ventricular wall thickness (16.0 \pm 2.3 and $6.7 \pm 1.3 \mathrm{~mm}$, respectively). In patients without cardiac complications and in the patient with DCM, several ventricular tissues were dissected from both ventricles as shown in Fig. 1 and Fig. 4. In patients with OMI, several blocks of ventricular tissues were also dissected from both infarcted and noninfarcted regions as illustrated in Fig. 3. Atrial tissues $(0.5-1.0 \mathrm{~g})$ were dissected from apical and proximal portions of bilateral auricles and nonauricle parts of both atria. Blocks were immediately frozen and stored at $-70^{\circ} \mathrm{C}$ until extraction.

Blood sampling. Blood samplings for the measurement of the plasma ANP concentration were performed from an antecubital vein a few days before the operation or within $1 \mathrm{wk}$ before death, as previously reported $(5,6,8)$.

Extraction of total RNA and Northern blotting analysis. Cardiac tissues obtained at the operation or within $5 \mathrm{~h}$ after death were used for the analysis of tissue ANPmRNA. Biopsy specimens were not used for this purpose because of small sizes of specimens $(2-4 \mathrm{mg})$. Total RNA was extracted from atrial and ventricular tissues in $4 \mathrm{M}$ guanidium thiocyanate buffer and the ANPmRNA level was measured by Northern blot analysis, as previously reported $(15,20,27)$. A ${ }^{32}$ P-labeled 581-bp restriction fragment of the human ANP complementary DNA was prepared by the random-priming method (30) with $\left[\alpha-{ }^{32} \mathrm{P}\right] \mathrm{dCTP}$ (Amersham International, Buckinghamshire, UK), and was used as a probe. ANPmRNA levels (arbitrary units) per $1 \mu \mathrm{g}$ of total RNA were expressed as relative levels to that in the apical portion of the right auricle obtained from patients with CAD and normal cardiac function (NYHA Functional Class I).

Extraction of ANP from tissues or plasma. Extraction of ANP from cardiac tissues was carried out as previously reported $(4,5,12,14,31)$. Extraction of ANP from plasma was performed using a Sep-Pak $C_{18}$ cartridge (Waters Associates Inc., Milford, MA) as previously reported $(5,6)$.

RIA for ANP. Measurement of tissue and plasma ANP levels were performed using the specific RIA for ANP $(5,6,14,32)$. This RIA recognizes the COOH-terminal portion of $\alpha$-human ANP, $\alpha$-human ANP (17-28). Cross-reactivities with $\beta$-human ANP and $\gamma$-human ANP in the RIA were 120 and $100 \%$, respectively, on a molar basis.

High performance gel permeation chromatography (HP-GPC). HP-GPC was performed on a TSK-GEL G2000 SW (Toyo Soda, Tokyo, Japan) column $(7.5 \times 600 \mathrm{~mm})$, eluted with $10 \mathrm{mM}$ trifluoroacetic acid containing $0.2 \mathrm{M}$ sodium chloride and $30 \%$ acetonitrile as a solvent, as previously reported $(7,12,14)$

Peptides. $\alpha$-Human ANP and $\gamma$-human ANP were donated by Drs. H. Matsuo and K. Kangawa (Miyazaki Medical College, Miyazaki, 
Table III. Clinical Diagnosis and Heart Weights in Patients with and without CHF

\begin{tabular}{|c|c|c|c|c|c|c|c|}
\hline Patient & Age & Sex & Diagnosis & $\begin{array}{l}\text { Time to autopsy } \\
\text { from death }\end{array}$ & Heart weight & Atrial weight & $\begin{array}{c}\text { Ventricular } \\
\text { weight }\end{array}$ \\
\hline & & & & $h$ & $g$ & $g$ & $g$ \\
\hline \multicolumn{8}{|c|}{ Patients without $\mathrm{CHF}$} \\
\hline 1 & 71 & F & Acute promyelocytic leukemia & 3.0 & 275 & 40 & 235 \\
\hline 2 & 68 & $\mathbf{F}$ & Gastric cancer & 3.0 & 250 & 30 & 220 \\
\hline 3 & 63 & $\mathbf{M}$ & Hepatocellular carcinoma & 12.0 & 350 & 50 & 300 \\
\hline 4 & 76 & $\mathbf{M}$ & Liver cirrhosis & 4.5 & 270 & 45 & 225 \\
\hline 5 & 63 & $\mathbf{M}$ & DIC & 5.0 & 300 & 40 & 260 \\
\hline Mean \pm SE & $68.2 \pm 2.5$ & & & $5.5 \pm 1.7$ & $299 \pm 26$ & $40 \pm 4.3$ & $269 \pm 32$ \\
\hline \multicolumn{8}{|c|}{ Patients with $\mathrm{CHF}$} \\
\hline 1 & 75 & $\mathbf{M}$ & Ant-Sep-OMI & 7.0 & 510 & 80 & 430 \\
\hline 2 & 57 & $\mathbf{M}$ & Ant-Sep-OMI & 5.5 & 380 & 40 & 340 \\
\hline 3 & 77 & $\mathbf{F}$ & CAVB Inf-OMI & 14.0 & 570 & 90 & 480 \\
\hline 4 & 53 & $\mathbf{M}$ & $\mathrm{DCM}$ & 3.0 & 460 & 95 & 365 \\
\hline Mean \pm SE & $65.5 \pm 6.1$ & & & $4.6 \pm 2.3$ & $480 \pm 40$ & $76 \pm 12$ & $404 \pm 32$ \\
\hline
\end{tabular}

CHF, congestive heart failure; DIC, Disseminated intravascular coagulation; Ant-Sep-OMI, antero-septal old myocardial infarction; CAVB, complete atrio-ventricular block; Inf-OMI, inferior old myocardial infarction; DCM, dilated cardiomyopathy.

Japan). $\beta$-Human ANP was generously supplied by Dr. K. Inouye (Shionogi Research Laboratories, Shionogi Co., Ltd., Osaka, Japan).

Hemodynamic measurement. PCWP and right atrial pressure were measured with a Swan-Ganz catheter (heparin-coated thermodilution catheter, model SP 5107; Gould Inc., Oxnard, CA) connected to a pressure transducer (P23ID; Gould Inc.) at the time of diagnostic catheterization and operation, as previously reported (8).

Statistical analysis. Data were expressed as mean \pm SE. Statistical analysis was performed using Student's $t$ test and Duncan's multiple range test when appropriate. Spearman's analysis was used to determine correlations between results.

\section{Results}

Plasma ANP concentrations. The plasma ANP concentration in patients with CHF ranged from 68.7 to $3,940.0 \mathrm{pg} / \mathrm{ml}$ with mean \pm SE of $690.0 \pm 283.7$ (Tables I, II, and IV), showing $\sim 20$-fold increase in comparison with that in normal subjects $(37.7 \pm 7.0 \mathrm{pg} / \mathrm{ml})(5)$.

\section{Tissue ANP levels and contents}

Normal heart. Tissue ANP levels in normal hearts are summarized in Fig. 1. The ANP level in several parts of the ventricle ranged from $4.2 \pm 1.0$ to $23.4 \pm 9.4 \mathrm{ng} / \mathrm{g}$, averaging $17.5 \pm 6.9$ $\mathrm{ng} / \mathrm{g}$. It was higher in the endocardial half of the ventricle than in the epicardial half $(40.8 \pm 16.8$ vs. $4.4 \pm 1.4 \mathrm{ng} / \mathrm{g})$. The atrial ANP level was $40.5 \pm 7.2 \mu \mathrm{g} / \mathrm{g}$. Thus, the ventricular ANP level was only $0.04 \%$ of the atrial level. The apical portion of normal right auricle showed the ANP level of $36.1 \pm 8.3 \mu \mathrm{g} / \mathrm{g}$, which was comparable to that in patients with CAD and normal cardiac function (from 24.0 to $46.8 \mu \mathrm{g} / \mathrm{g}$, mean $\pm \mathrm{SE} ; 29.7 \pm 5.3$ $\mu \mathrm{g} / \mathrm{g}$ ). Therefore, the postmortem degradation of ANP was considered to be if any minimal in normal hearts obtained at autopsy. Taking atrial and ventricular weights into account, total ANP contents in the atrium and ventricle were $1,728 \pm 447$ and $4.1 \pm 1.7 \mu \mathrm{g}$, respectively. The total content in the ventricle was $0.26 \%$ of that in the atrium.

Failing heart (samples obtained at operation and at biopsy). The tissue ANP level in the left ventricular aneurysm was $660.3 \pm 122.2 \mathrm{ng} / \mathrm{g}$ and was $\sim 40$ times higher than that in the corresponding apical part of the normal ventricle (Table I). When the aneurysm was divided into the endocardial and epicardial halves, the former contained higher amounts of ANP than the latter $(1,016.4 \pm 152.1$ vs. $167.2 \pm 37.8 \mathrm{ng} / \mathrm{g})$. The ANP level in the aneurysm was $1.4 \pm 0.1 \%$ of that in the atrium of the

Table IV. Levels and Contents of Tissue ANP in Patients with OMI

\begin{tabular}{|c|c|c|c|c|c|c|c|c|c|c|}
\hline \multirow[b]{3}{*}{ Patient } & \multirow{3}{*}{$\begin{array}{l}\text { Plasma ANP } \\
\text { concentration }\end{array}$} & \multicolumn{6}{|c|}{ Tissue ANP level } & & & \\
\hline & & \multicolumn{2}{|c|}{ Atrium } & \multicolumn{2}{|c|}{ Left ventricle } & \multirow{2}{*}{$\frac{\text { Ventricle }}{\text { Average }}$} & \multirow[b]{2}{*}{ V/A } & \multicolumn{3}{|c|}{ Tissue ANP content } \\
\hline & & ARAu & Average & Infarcted-LV & Noninfarcted-LV & & & Atrium & Ventricle & V/A \\
\hline & $p g / g$ & $\mu g / g$ & $\mu g / g$ & $n g / g$ & $n g / g$ & $n g / g$ & $\%$ & $\mu g$ & $\mu g$ & $\%$ \\
\hline 1 & 1,272 & 73.4 & 177.7 & $1,011.7$ & 918.8 & 939.8 & 0.53 & 14,216 & 404 & 2.84 \\
\hline 2 & 139 & 83.3 & 73.6 & 92.0 & 311.7 & 145.9 & 0.20 & 2,944 & 50 & 1.68 \\
\hline 3 & - & 81.0 & 81.6 & 54.6 & 304.5 & 148.8 & 0.18 & 7,344 & 71 & 0.97 \\
\hline \multirow[t]{2}{*}{ Mean $\pm S E$} & - & 79.2 & 111.0 & 386.1 & 511.7 & 411.5 & 0.30 & 8,168 & 175 & 1.83 \\
\hline & & \pm 3.0 & \pm 33.5 & \pm 313.0 & \pm 203.6 & \pm 264.2 & \pm 0.11 & $\pm 3,280$ & \pm 115 & \pm 0.54 \\
\hline
\end{tabular}

ANP, atrial natriuretic polypeptide; ARAu, apical portion of right auricle; $\mathrm{A}$, atrium; $\mathrm{V}$, ventricle; $\mathrm{LV}$, left ventricle. 


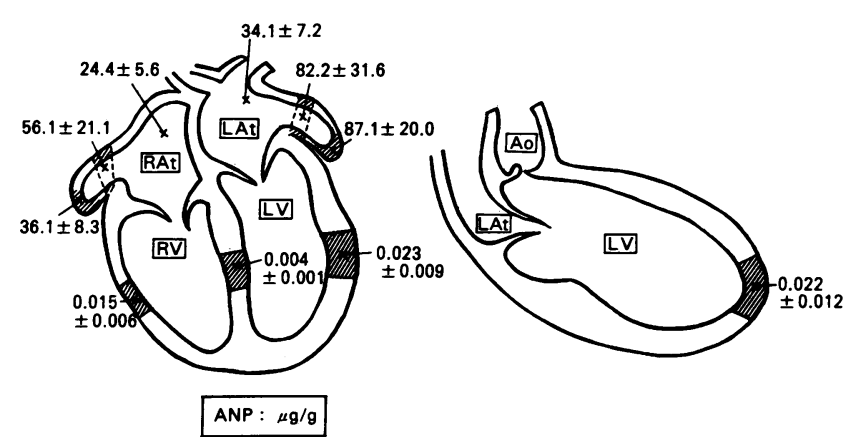

Figure 1. ANP levels in atrium and ventricle of the normal heart. RAt, LAt, RV, LV and Ao mean right atrium, left atrium, right ventricle, left ventricle and aorta, respectively. The ANP level averaged $40.5 \pm 7.2 \mu \mathrm{g} / \mathrm{g}$ in the atrium and $17.5 \pm 6.9 \mathrm{ng} / \mathrm{g}$ in the ventricle.

same heart. Fig. 2 shows tissue ANP levels in a representative case of left ventricular aneurysm (patient 6). Although an increase in the ANP level of transmurally scarred tissue (as shown in shaded portions in Fig. 2) was not prominent, ANP levels in tissues adjacent to the scarred region were markedly increased. There was a positive correlation between the maximal ANP level in each left ventricular aneurysm and PCWP ( $r$ $=0.85, P<0.05)$ or the ANP level in the apical portion of right auricle $(r=1.00, P<0.01)$. The plasma ANP concentration is also correlated with the ANP level in the apical portion of the right auricle $(r=0.83, P<0.05)$ and that in aneurysm $(r$ $=0.83, P<0.05)$.

The ANP level in the DCM ventricle obtained at biopsy was also increased to $3,138.4 \pm 1,642.1 \mathrm{ng} / \mathrm{g}$ (Table II).

Failing heart (autopsy samples). Fig. 3 shows ANP levels in several regions of the heart in a representative patient with OMI (patient 1). Tissue ANP levels in infarcted and noninfarcted regions of the ventricle were 1,011.7 200.9 and $918.8 \pm 538.8 \mathrm{ng} / \mathrm{g}$, respectively. The ANP level in the right ventricle was also increased to $125.4 \pm 50.4 \mathrm{ng} / \mathrm{g}$. The remaining two patients with OMI also showed increased ANP levels in both infarcted and noninfarcted regions of the ventricle (Table IV). The average ANP levels in the ventricle and atrium in these patients were $411.5 \pm 264.2 \mathrm{ng} / \mathrm{g}$ and $111.0 \pm 33.5 \mu \mathrm{g} / \mathrm{g}$, respectively. Thus, the percentage of the ventricular to atrial ANP level was $0.31 \pm 0.09 \%$. Total ANP content in the ventricle was $1.87 \pm 0.37 \%$ of that in the atrium, because ventricular weight was about six times heavier than atrial weight.

The DCM heart also showed a 10-50-fold increase in ANP levels compared with normal hearts in various parts of the ventricle as shown in Fig. 4. In the atrium, however, the average of ANP levels in DCM was only about two times higher than that of normal hearts (70.7 vs. $40.5 \pm 7.2 \mu \mathrm{g} / \mathrm{g})$. The ventricular ANP level was $1.4 \%$ of the atrial ANP level. The total

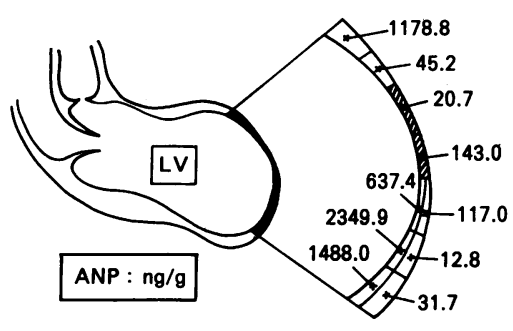

Figure 2. ANP levels in the left ventricular aneurysm (patient 6). The shaded portion indicates the transmural scar. ANP levels in the left ventricular aneurysm increased to 918.0 $\mathrm{ng} / \mathrm{g}$ in average. The $\mathrm{ab}-$ breviation is the same as in Fig. 1.

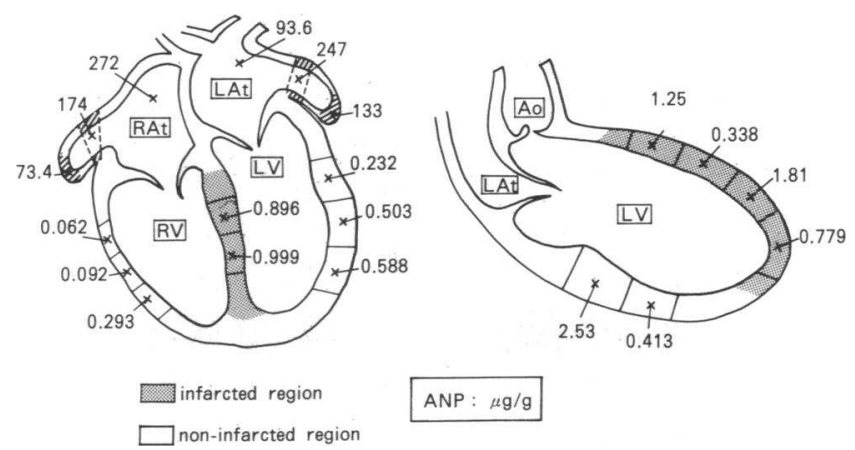

Figure 3. ANP levels in the OMI heart (patient 1). Hatched portions indicate infarcted regions. ANP levels in infarcted and non-infarcted regions were $1,011.7 \pm 200.9 \mathrm{ng} / \mathrm{g}$ and $918.8 \pm 538.8 \mathrm{ng} / \mathrm{g}$, respectively. Abbreviations are the same as in Fig. 1.

ANP content in the DCM atrium and ventricle were 6,717 and $365 \mu \mathrm{g}$, respectively. The total ANP content in the DCM ventricle was $5.4 \%$ of that in the DCM atrium and was $21 \%$ of that in the normal atrium.

\section{Northern blot analysis}

Normal heart. Northern blot analysis of RNA from the atrium and ventricle revealed that total RNA extracted from normal atrium and ventricle contained a hybridizing RNA band of $\sim 950$ bp (Fig. 5). The ANPmRNA level of the apical portion of the normal right auricle was $930 \pm 130 \mathrm{mU} / \mu \mathrm{g}$ RNA ranging from 670 RNA to $1,600 \mathrm{mU} / \mu \mathrm{g}$ RNA. This level was comparable to that in patients with $C A D$ and normal cardiac function $(1,000 \pm 170 \mathrm{mU} / \mu \mathrm{g}$ RNA), suggesting that postmortem degradation of ANPmRNA was also minimal in normal hearts examined. The ANPmRNA level in the left ventricle was $16 \pm 8$ $\mathrm{mU} / \mu \mathrm{g}$ RNA and was $\sim 2.4 \pm 1.2 \%$ of that in the atrium of the same patient. The total contents of ANPmRNA in the ventricle and atrium were $1,000 \pm 490 \mathrm{U}$ and 7,300 $\pm 570 \mathrm{U}$, respectively. The percentage of ventricular to atrial ANPmRNA content was $13.4 \pm 6.5 \%$.

Failing heart. The ANPmRNA from the right auricle or ventricle in patients with $\mathrm{CHF}$ was the same size (950 bp) as normal atrial ANPmRNA (Fig. 5). The ANPmRNA level in the left ventricular aneurysm was increased to $140 \pm 40 \mathrm{mU} / \mu \mathrm{g}$ RNA (from $45 \mathrm{mU} / \mu \mathrm{g}$ of RNA to $250 \mathrm{mU} / \mu \mathrm{g}$ RNA), being about one order of magnitude higher than the normal ventricular level. There was a positive correlation between the

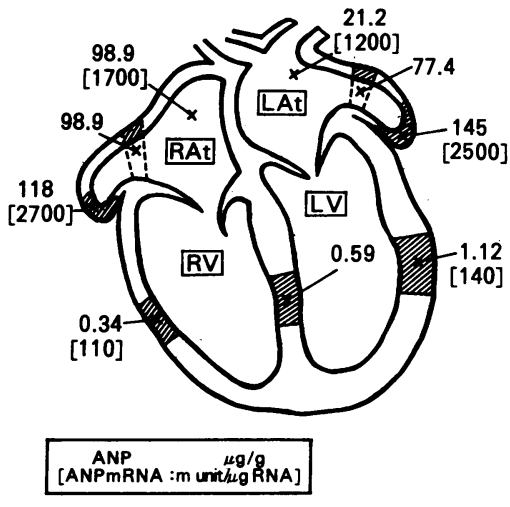

Figure 4. ANP and ANPmRNA levels in the DCM heart. The ANP level is expressed as $\mu \mathrm{g} / \mathrm{g}$ and the ANPmRNA level as $\mathrm{mU} / \mu \mathrm{g}$ RNA in square brackets (see Methods). The mean ANP levels in the atrium and ventricle were 70.7 and 1.0 $\mu \mathrm{g} / \mathrm{g}$, respectively. The ANPmRNA level in the atrium and ventricle of the DCM heart showed

2- and 10-fold increases, respectively, compared with those of the normal heart. Abbreviations are the same as in Fig. 1. 


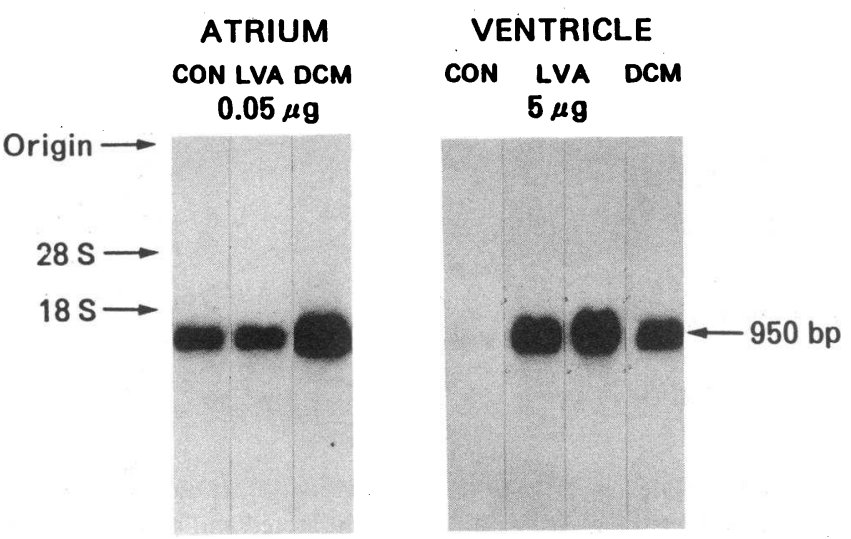

Figure 5. Northern blot analysis of RNA from the normal and failing hearts. $50 \mathrm{ng}$ of total RNA from atria and $5 \mu \mathrm{g}$ of total RNA from ventricles were fractionated on agarose gel. Results of Northern blot analysis in representative cases are shown (atrium: CON; patient 1, LVA; patient 5, and DCM; 4 [autopsy], ventricle: CON; patient 1, LVA [left]; patient 2, LVA [right]; patient 5, and DCM; patient 4 [autopsy]).

ANPmRNA level in the left ventricular aneurysm and PCWP $(r=0.70, P<0.10)$. The ANPmRNA level in the apical portion of the right auricle in these patients was not significantly different from that in the normal atrium $(630 \pm 170 \mathrm{mU} / \mu \mathrm{g}$ RNA vs. $1,000 \pm 170 \mathrm{mU} / \mu \mathrm{g}$ RNA). Thus, the ventricle contained $22.6 \pm 4.7 \%$ of ANPmRNA mU per $\mu \mathrm{g}$ RNA compared with the atrial level.

The ANPmRNA level in right and left ventricles of the DCM heart were $110 \mathrm{mU} / \mu \mathrm{g}$ RNA and $140 \mathrm{mU} / \mu \mathrm{g}$ RNA, respectively (average $130 \mathrm{mU} / \mu \mathrm{g}$ RNA). This level was $\sim 7 \%$ of the ANPmRNA level in the atrium of the same heart (Fig. 4). The ANPmRNA level in the DCM atrium was two times higher than that in the normal atrium $(1,800 \mathrm{mU} / \mu \mathrm{g}$ RNA vs. $930 \mathrm{mU} / \mu \mathrm{g}$ RNA). The total ANPmRNA content in the DCM ventricle was $\sim 30 \%$ of that in the DCM atrium $(9,500 \mathrm{U})$ and was comparable to that in the normal atrium $(9,500 \mathrm{U}$ vs. 7,300 U).

Ratio of the ANP level to the ANPMRNA level (ANP) $A N P m R N A$ ratio). The ratios of ANP/ANPmRNA in normal and failing ventricles were 10 -fold less than those in atria of the same hearts, as shown in Table V.

$H P$-GPC profiles. To elucidate the molecular form of ANP in the atrium and ventricle of the failing heart, atrial and ventricular extracts from patients with left ventricular aneurysm and DCM (except one patient examined at autopsy) were analyzed by HP-GPC. $\alpha$-Human ANP-like immunoreactivity ( $\alpha$ human ANP-LI) applied to the HP-GPC column ranged from 2.0 to $9.9 \mathrm{ng}$, and total $\alpha$-hANP-LI recovered in all HP-GPC fractions was $86.2 \pm 6.3 \%$ in atrial extracts and $70.2 \pm 8.2 \%$ in ventricular extracts. The predominant component of $\alpha$ human ANP-LI in each extract from the normal atrium and ventricle was $\gamma$-human ANP. Fig. 6 shows HP-GPC profiles of extracts of the right atrium and aneurysm tissue of representative two patients with left ventricular aneurysm. In three of six patients with left ventricular aneurysm, the HP-GPC profile of extracts from the right auricle revealed that $\alpha$-human ANP-LI consisted of a large molecular form, $\gamma$-human ANP, and low molecular form(s), $\alpha$-human ANP and/or $\beta$-human ANP. In the remaining three patients, only $\alpha$-human ANP and/or $\beta$ -
Table V. Ratios of ANP Level to ANPmRNA Level in Normal and Failing Hearts

\begin{tabular}{lccccc}
\hline & \multicolumn{3}{c}{ ANP/ANPmRNA ratio $\left(\mu \mathrm{g} \cdot \mathrm{g}^{-1} \mathrm{U}^{-1} \cdot \mu \mathrm{g}\right.$ RNA $)$} \\
\cline { 2 - 3 } \cline { 5 - 6 } & \multicolumn{2}{c}{ Control } & & \multicolumn{2}{c}{ Diseased heart } \\
\cline { 2 - 3 } \cline { 5 - 6 } & NYHA I & Autopsy & & $\mathrm{LV}$ aneurysm & DCM \\
\hline Atrium & $31.9 \pm 5.8$ & $42.8 \pm 13.1$ & & $89.8 \pm 15.5$ & 71 \\
Ventricle & - & $3.2 \pm 1.7^{*}$ & & $15.4 \pm 4.8^{*}$ & 11 \\
V/A \% & - & $10.0 \pm 6.2$ & & $14.6 \pm 3.8$ & 15.5 \\
& & & & & \\
\hline
\end{tabular}

Results in the DCM heart were derived from those in the patient with DCM who was examined after death. In the calculation of V/A $\%$, the value of $\mathrm{V} / \mathrm{A} \%$ in each patient was obtained and the mean value was calculated.

* $P<0.01$ vs. the ratio of ANP/ANPmRNA in the atrium of the same heart.

human ANP were detected in the HP-GPC analysis. Mean percentages of $\alpha$-human ANP, $\beta$-human ANP and $\gamma$-human ANP in $\alpha$-human ANP-LI in right atrial extracts were $51.0 \pm 17.2 \%, 12.0 \pm 8.4 \%$, and $37.0 \pm 17.1 \%$, respectively. However, the HP-GPC profile of extracts from left ventricular aneurysm revealed that the predominant component of $\alpha$ human ANP-LI was $\gamma$-human ANP with a little amount of small molecular weight forms. Mean percentages of $\alpha$-human ANP, $\beta$-human ANP, and $\gamma$-human ANP in $\alpha$-human ANP$L I$ in the extract from the left ventricular aneurysm were $1.5 \pm 0.5 \%, 1.9 \pm 1.0 \%$, and $96.7 \pm 0.9 \%$, respectively.

In three of four patients with DCM, only $\gamma$-human ANP was detected in the extract of the ventricular biopsy specimens. However, in one patient whose ANP level in the ventricle was the highest $(6,916 \mathrm{ng} / \mathrm{g}), 45 \%$ of total $\alpha$-human ANP-LI was small molecular forms of ANP ( $\alpha$-human ANP: $12 \%, \beta$ human ANP: 33\%). Mean percentages of $\alpha$-human ANP, $\beta$ -

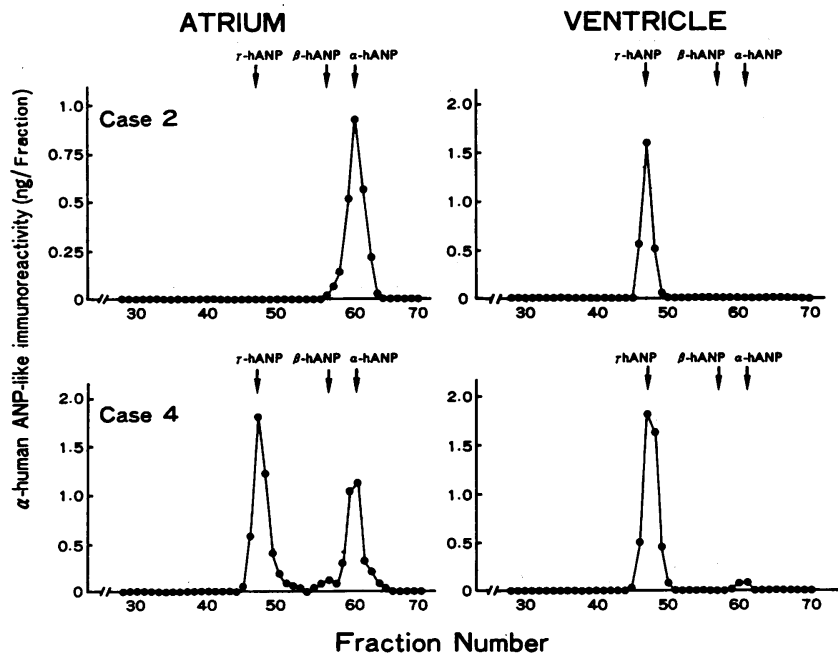

Figure 6. HP-GPC profiles of extracts from the right auricle and the left ventricular aneurysm. Results from patients 2 (upper panel) and 4 (lower panel) are represented. The predominant component of $\alpha$ human ANP-like immunoreactivity ( $\alpha$-human ANP-LI) in extracts from failing ventricles was $\gamma$-human ANP ( $\gamma$-hANP), although small molecular forms of ANP, $\beta$-human ANP ( $\beta$-hANP) and/or $\alpha$-human ANP $(\alpha$-hANP), were prevailing in extracts from failing atria. 
human ANP and $\gamma$-human ANP in $\alpha$-human ANP-LI in ventricular extracts from DCM hearts were $4.2 \pm 2.7 \%, 9.2 \pm 7.9 \%$, and $86.6 \pm 10.6 \%$, respectively.

\section{Discussion}

Our previous study has shown that the ANP concentration in the right atrium is increased with the severity of CHF in patients with a variety of heart diseases (12). The present study confirmed this observation, showing an increase in atrial ANP levels in six patients with left ventricular aneurysm. The present study demonstrates increases in ANP and ANPmRNA levels in various parts of ventricles of DCM and in infarcted and noninfarcted portions of OMI hearts. These results are consistent with recent reports that ANP-like immunopositive substances are abundantly found in ventricular myocytes, but not in other cellular elements, of DCM or OMI hearts $(28,29)$. All these observations indicate that the expression of the ANP gene is increased in cardiomyocytes of the entire ventricle in the human failing heart. A positive correlation was found between the maximal ANP levels in ventricular aneurysm tissues and PCWP, suggesting that the ventricular ANP gene expression is increased with the severity of CHF as is the case of atrial ANP gene expression (12). It is noteworthy, however, that the percent increase of ANP and ANPmRNA levels in the ventricle is more prominent than that in the atrium of the failing heart. That is, two to three times increase of the ANP level was found in the DCM or OMI atrium compared with the normal atrium, whereas 40-50 times increase was found in the ventricle. In addition, the ANPmRNA level in the ventricle showed also 10 times increase in aneurysm or DCM tissues compared with normal ventricles. The ANP gene expression in the ventricle of the failing heart was more prominent in the endocardial than in the epicardial half.

In the present study, the DCM ventricle obtained at autopsy contained $7 \%$ of the ANPmRNA of the atrium in the concentration. The total ANPmRNA content in the DCM ventricle was $30 \%$ of that in the DCM atrium and was much the same as that in the normal atrium. Similarly, the ANPmRNA level in the ventricle with aneurysm reached $23 \%$ of that in the atrium of the same heart. Therefore, the total content of ANPmRNA in the failing ventricle is comparable to that in the normal atrium. These results suggest that the failing ventricle secretes a considerable amount of ANP and contributes to the elevation of the plasma ANP concentration in patients with CHF. Our unpublished observation demonstrates that the difference between the plasma ANP levels in the aorta and those in the interventricular vein draining the blood from the ventricle is much greater in patients with DCM than in control patients, indicating augmented secretion of ANP from the failing ventricle. In addition, we have recently reported that the total amount of ANPmRNA in the ventricle is about three times larger than that in the atrium in SHR-stroke prone (20). It is possible, therefore, that the amount of ANP secreted from the ventricle may exceed that from the atrium in some patients with severe CHF.

In this study the plasma ANP concentration in patients with CHF was about 20 times higher than that in normal subjects. The data of ANPmRNA suggest that the total amount of ANPmRNA in the whole failing heart is increased by about three- to fourfold in comparison with that in the whole normal heart. Therefore, these findings suggest that the increased expression of the ANP gene in the failing heart may not be sufficient to account for the elevation of the plasma ANP level in CHF, although the possibility that accelerated secretion and altered turnover of ANPmRNA in the failing heart cannot be ruled out. The discrepancy may be explained in part by decreased clearance of circulating ANP in CHF, which might relate to down regulation of ANP receptors in CHF (33).

Simultaneous increases in ANPmRNA and ANP levels in the ventricle of the failing heart indicate that ANPmRNA is actually translated to ANP in the ventricle. However, the ANP/ANPmRNA ratio in the ventricle was smaller than that in the atrium in patients with OMI and DCM as well as in control subjects. A pulse-chase experiment recently performed by Bloch et al. showed that neonatal ventricular cardiocytes of rats in culture release ANP more rapidly after synthesis than atrial cardiocytes (17). Our results along with those by Bloch et al. raise the possibility that ANP is secreted from the ventricle more rapidly than from the atrium. Further studies are necessary to clarify whether or not synthesis, storage and secretion of ANP in the ventricle are different from those in the atrium $(17,34)$.

Another interesting finding in the present study is that molecular forms of ANP in the ventricle differs from those in the atrium in a condition of CHF. It is known that $\gamma$-human ANP is the predominant storage form of ANP in the normal atrium and ventricle. We recently observed that $\alpha$-human ANP and/ or $\beta$-human ANP, especially $\beta$-human ANP were prevailing in auricular extracts from patients with severe CHF (12). In the present study, the HP-GPC profile of auricular extracts from CHF showed that $\sim 60 \%$ of total $\alpha$-human ANP-LI was small molecular weight forms. In contrast, in nine patients with left ventricular aneurysm or DCM, except one patient with DCM, $\gamma$-human ANP was predominant in ventricular extracts. These findings indicate that the predominant component of ANP in extract of the ventricle is $\gamma$-human ANP, a precursor form of $\alpha$-human ANP, even under the condition of CHF. A rapid turnover of ANP in ventricular myocytes suggested above might be related to the difference in molecular forms of ANP between the ventricle and atrium.

The gene expression of ANP in the ventricle has been reported to be increased in neonatal rats and decreased during the first week of life (18). We have also reported that the ANP concentration in the ventricle is more than $1 \mu \mathrm{g} / \mathrm{g}$ in human fetuses at 14 and 22 wk gestation, that it decreases in parallel with fetal development, and that adult ventricle contains $<50$ $\mathrm{ng} / \mathrm{g}$ of ANP (35). These results indicate that the expression of the ANP gene is reinduced in the ventricle of patients with CHF. It is well documented that contractile protein isoforms are reinduced in human and animal hearts under various pathological conditions $(25,36-39)$. The mechanism responsible for the reinduction of the ANP gene in the failing ventricle is not clear at present. The aortic ligation and aortovenous fistula were reported to cause the augmented expression of the ANP gene in the rat ventricle in association with ventricular hypertrophy (23-25). In addition, the expression of the ANP gene is markedly increased in ventricles of SHR and SHRstroke prone at the stage of established hypertension and ventricular hypertrophy $(20,21)$. In the present study, concomitant increases in the ANP gene expression and ventricular mass were observed in patients with OMI and DCM, and a positive significant correlation was found between PCWP, or 
left ventricular end-diastolic pressure, and the maximal ANP level in the left ventricular aneurysm. All these results suggest that ventricular hypertrophy and the augmented expression of the ANP gene in the ventricle may be induced by the common mechanism and that ventricular stretch due to an increase in after- or preload on the ventricle leads to the reinduction of the ANP gene. The observation that an endocardial half of the ventricle contained more ANP than an epicardial half also supports the concept of stretch induced reinduction of the ANP gene, because the wall tension in the endocardial half is greater than that in the epicardial half (40). Further studies are necessary to clarify the precise mechanism of the augmented expression of the ANP gene in the ventricle, and the relationship between the augmented expression of the ANP gene and ventricular hypertrophy.

What is the significance of the augmented expression of the ANP gene in the ventricle? Since the intravenous infusion of ANP improves left ventricular function in CHF, we have proposed that augmented ANP synthesis in the atrium is a compensatory mechanism $(8,41,42) .{ }^{2}$ The present study further indicates that the ventricle also possesses the self-compensatory mechanism, an increase of ANP secretion, like autoregulation (Frank-Starling law of the heart) and hypertrophy (43).

\section{Acknowledgments}

We thank Drs. N. Morii, S. Shiono, and G. Shirakami in our laboratory for their encouragement and advice, Drs. A. Yamazato, M. Aoshima and T. Takeda in Kyoto Takeda Hospital, and clinical staffs of the cardiac catheterization laboratory in Kumamoto University Hospital for their assistance in tissue samplings, and Miss C. Nakai for her technical assistance. The excellent secretarial work of Mrs. H. Tabata and Miss A. Furu is also acknowledged.

This work was supported in part by research grants from the Japanese Ministry of Education, Science and Culture, the Japanese Ministry of Health and Welfare "Disorders of Adrenal Hormone" Research Committee, Japan, 1987, Life Science Research Project of Institute of Physical and Chemical Research (RIKEN), Japan Tobacco Inc. and Yamanouchi Foundation for Research on Metabolic Disorders, by research grants for cardiovascular diseases (60A-3 and 62 $A^{\prime}-1$ ) from the Japanese Ministry of Health and Welfare.

\section{References}

1. De Bold, A. J. 1985. Atrial natriuretic factor: a hormone produced by the heart. Science (Wash. DC). 230:767-770.

2. Needleman, P., S. P. Adams, B. R. Cole, M. G. Currie, D. M. Geller, M. L. Michener, C. B. Saper, D. Schwartz, and D. G. Standaert. 1985. Atriopeptins as cardiac hormones. Hypertension. 7:469-482.

3. Cantin, M., and J. Genest. 1985. The heart and the atrial natriuretic factor. Endocr. Rev. 6:107-127.

4. Kangawa; K., and H. Matsuo. 1984. Purification and complete amino acid sequence of $\alpha$-human atrial natriuretic polypeptide. Biochem. Biophys. Res. Commun. 118:131-139.

5. Sugawara, A., K. Nakao, N. Morii, M. Sakamoto, M. Suda, M. Shimokura, Y. Kiso, M. Kihara, Y. Yamori, K. Nishimura, J. Soneda, T. Ban, and H. Imura. 1985. $\alpha$-Human atrial natriuretic polypeptide is released from the heart and circulates in the body. Biochem. Biophys. Res. Commun. 129:439-446.

2. During the revision of our paper, Edwards et al. reported morphological evidence for the presence of ANP in the ventricle of the human failing heart (44), being consistent with our recent immunohistochemical study (28).
6. Sugawara, A., K. Nakao, N. Morii, M. Sakamoto, K. Horii, M. Shimokura, Y. Kiso, K. Nishimura, T. Ban, M. Kihara, Y. Yamori, K. Kangawa, H. Matsuo, and H. Imura. 1986. Significance of $\alpha$-human atrial natriuretic polypeptide as a hormone in man. Hypertension. 8(Suppl. I):I-151-155.

7. Nakao, K., A. Sugawara, S. Shiono, Y. Saito, N. Morii, T. Yamada, H. Itoh, M. Mukoyama, H. Arai, M. Sakamoto, and H. Imura. 1987. Secretory form of atrial natriuretic polypeptide as cardiac hormone in humans and rats. Can. J. Physiol. Pharmacol. 65:1756-1761.

8. Saito, Y., K. Nakao, K. Nishimura, A. Sugawara, K. Okumura, K. Obàta, R. Sonoda, T. Ban; H. Yasue, and H. Imura. 1987. Clinical application of atrial natriuretic polypeptide in patients with congestive heart failure: beneficial effects on left ventricular function. Circulation. 76:115-124.

9. Tikkanen, I., F. Fyhrquist, K. Metsarinne, and R. Leidenius. 1985. Plasma atrial natriuretic peptide in cardiac disease and during infusion in healthy volunteers. Lancet. ii:66-69.

10. Burnett, J. C., Jr., P. C. Kao, D. C. Hu, D. W. Heser, D. Heublein, J. P. Granger, T. J. Opgenorth, and G. S. Reeder. 1986. Atrial natriuretic peptide elevation in congestive heart failure in man. Science (Wash. DC). 231:1145-1147.

11. Sugawara, A., K. Nakao, K. Nishimura, N. Morii, M. Sakamoto, T. Yamada, H. Itoh, S. Shiono, Y. Saito, T. Ban, and H. Imura. 1987. Atrial natriuretic polypeptide secretion and central hemodynamics in man. In American Society of Hypertension Symposium Series "Biologically Active Atrial peptide." B. M. Brenner and J. H. Laragh, editors. Vol. 1. Raven Press, New York. 436-439.

12. Sugawara, A., K. Nakao, N. Morii, T. Yamada, H. Itoh, S. Shiono, Y. Saito, M. Mukoyama, H. Arai, K. Nishimura, K. Obata, H. Yasue, T. Ban, and H. Imura. 1988. Synthesis of atrial natriuretic polypeptide (ANP) in human failing hearts. Evidence for altered processing of ANP precursor and augmented synthesis of $\beta$-human ANP. J. Clin. Invest. 81:1962-1970.

13. De Bold, A. J., H. B., Borenstein, A. T. Veress, and H. Sonnenberg. 1981. A rapid and potent natriuretic response to intravenous injection of atrial myocardial extracts in rats. Life Sci. 28:89-94.

14. Nakao, K., A. Sugawara, N. Morii, M. Sakamoto, M. Suda, J. Soneda, T. Ban, Y. Yamori, M. Shimokura, Y. Kiso, and H. Imura. 1984. Radioimmunoassay for $\alpha$-human and rat atrial natriuretic polypeptide. Biochem. Biophys. Res. Commun. 124:815-821.

15. Nakayama, K., H. Ohkubo, T. Hirose, S. Inayama, and S. Nakanishi. 1984. mRNA sequence for human cardiodilatin-atrial natriuretic factor precursor and regulation of precursor mRNA in rat atria. Nature (Lond.). 310:699-701.

16. Yamanaka, M., B. Greenberg, L. Johnson, J. Seilhamer, M. Brewer, T. Friedemann, J. Miller, S. Atlas, J. Laragh, J. Lewicki, and J. Fiddes. 1984. Cloning and sequence analysis of the cDNA for the rat atrial natriuretic factor precursor. Nature (Lond.). 309:719-722.

17. Bloch, K. D., J. G. Seidman, J. D. Naftilan, J. T. Fallon, and C. E. Seidman. 1986. Neonatal atria and ventricles secrete atrial natriuretic factor via tissue-specific secretory pathways. Cell. 47:695-702.

18. Gardner, D. G., C. F. Deschepper, W. F. Ganong, S. Hane, J. Fiddes, J. D. Baxter, and J. Lewicki. 1986. Extra-atrial expression of the gene for atrial natriuretic factor. Proc. Natl. Acad. Sci. USA. 83:6697-6701.

19. Nemer, M., J. P. Lavigne, J. Drouin, G. Thibault, M. Gannon, and T. Antakly. 1986. Expression of atrial natriuretic factor gene in heart ventricular tissue. Peptides. 7:1147-1152.

20. Arai, H., K. Nakao, Y. Saito, N. Morii, S. Sugawara, T. Yamada, H. Itoh, S. Shiono, M. Mukoyama, H. Ohkubo, S. Nakanishi, and $H$. Imura. 1988. Augmented expression of atrial natriuretic polypeptide (ANP) gene in ventricles of spontaneously hypertensive rats (SHR) and SHR-stroke prone. Circ. Res. 62:926-930.

21. Takayanagi, R., T. Imada, and T. Inagami. 1987. Synthesis and presence of atrial natriuretic factor in rat ventricle. Biochem. Biophys. Res. Commun. 142:483-488.

22. Ding, J., G. Thibault, J. Gutkowska, R. Garcia, T. Karabatsos, G. Jasmin, J. Genest, and M. Cantin. 1987. Cardiac and plasma atrial 
natriuretic factor in experimental congestive heart failure. Endocrinology. 121:248-257.

23. Day, M. L., D. Schwartz, R. C. Wiegand, P. T. Stockman, S. R. Brunnert, H. E. Tolunay, M. G. Currie, D. G. Standaert, and P. Needleman. 1987. Ventricular atriopeptin: unmasking of messenger RNA and peptide synthesis by hypertrophy or dexamethasone. Hypertension. 9:485-491.

24. Lattion, A. L., J. B. Michel, P. Corvol, and F. Soubrier. 1986. All of the rat myocardium expresses ANF gene during volume overload. J. Hypertension. 4(Suppl. 6):S486-S488.

25. Izumo, S., B. Nadal-Ginart, and V. Mahdavi. 1987. Protooncogene induction and reprogramming of cardiac gene expression produced by pressure overload. Proc. Natl. Acad. Sci. USA. 85:339-343.

26. Morii, N., K. Nakao, A. Matsumori, N. Tomioka, A. Sugawara, T. Yamada, H. Itoh, S. Shiono, Y. Saito, M. Mukoyama, H. Arai, C. Kawai, and H. Imura. 1987. Atrial natriuretic polypeptide (ANP) in mice with experimental viral moycarditis. Alteration in atrial, ventricular and plasma ANP levels. Jpn. Circ. J. 51:906. (Abstr.)

27. Saito, Y., K. Nakao, H. Arai, A. Sugawara, N. Morii, T. Yamada, H. Itoh, S. Shiono, M. Mukoyama, K. Obata, H. Yasue, H. Ohkubo, S. Nakanishi, and H. Imura. 1987. Atrial natriuretic polypeptide (ANP) in human ventricle. Increased gene expression of ANP in dilated cardiomyopathy. Biochem. Biophys. Res. Commun. 148:211217.

28. Yamada, H., Y. Saito, M. Mukoyama, K. Nakao, H. Yasue, T. Ban, H. Imura, and Y. Sano. 1988. Immunohistochemical localization of atrial natriuretic polypeptide (ANP) in human atrial and ventricular myocardiocytes. Histochemistry. 89:411-413.

29. Tsuchimochi, H., Y. Yazaki, H. Ohno, R. Takanashi, and F. Takaku. 1987. Ventricular expression of atrial natriuretic peptide. Lancet. ii:336-337.

30. Maniatis, T., E. F. Fritsch, and J. Sambrook. 1982. Biochemical techniques in molecular cloning: A laboratory manual. Cold Spring Harbor Laboratory, Cold Spring Harbor, NY. 448.

31. Kangawa, K., A. Fukuda, and H. Matsuo. 1985. Structural identification of $\beta$ - and $\gamma$-human atrial natriuretic polypeptide. Nature (Lond.). 313:397-400.

32. Morii, N., K. Nakao, M. Kihara, Y. Yamori, and H. Imura. 1985. Occurrence of atrial natriuretic polypeptide in brain. Biochem. Biophys. Res. Commun. 127:413-419.
33. Schiffrin, E. L., M. Deslongchamps, and G. Thibault 1986. Platelet binding sites for atrial natriuretic factor in humans-characterization and effects of sodium intake. Hypertension. 8(Suppl. II):II6-II-10.

34. Kelly, R. B. 1985. Pathways of protein secretion in eukaryotes. Science (Wash. DC). 230:25-32.

35. Kikuchi, K., K. Nakao, R. Hayashi, N. Morii, A. Sugawara, M. Sakamoto, H. Imura, and H. Mikawa. 1987. Ontogeny of atrial natriuretic polypeptide in human heart. Acta Endocrinol. 115:211-217.

36. Hirzel, H. O., C. R. Tuchschmid, J. Schneider, H. P. Krayenbuehl, and M. C. Schaub. 1985. Relationship between myosin isoenzyme composition, hemodynamics, and myocardial structure in various forms of human cardiac hypertrophy. Circ. Res. 57:729-740.

37. Delaney, P., S. Vitek, L. Cribbs, and M. A. Q. Siddiqui. 1985. Increased levels of myosin mRNAs in spontaneously hypertensive rat heart. Biochem. Biophys. Res. Commun. 132:820-828.

38. J. J. Mercadier, A. M. Lompre, C. Wisnewsky, J. L. Samuel, J. Bercovici, B. Swynghedauw, and K. Schwartz. 1981. Myosin isoenzymic changes in several models of rat cardiac hypertrophy. Circ. Res. 49:525-532.

39. Schwartz, K. D., de la Bastic, P. Bouveret, P. Oliveiro, S. Alonso, and M. Buckingham. 1986. $\alpha$-skeletal muscle action mRNAs accumulate in hypertrophied adult rat hearts. Circ. Res. 59:551-555.

40. Katz, A. M. 1977. The heart as a muscular pump. In Physiology of the heart. M. Katz, editor. Raven Press Books, Ltd., New York, pp 197-208.

41. Cody, R. J., S. A. Atlas, J. H. Laragh, S. H. Kubo, A. B. Covit, K. S. Ryman, A. Shaknovich, K. Pondolfino, M. Clark, M. J. F. Camargo, R. M. Scarborough, and J. A. Lewicki. 1986. Atrial natriuretic factor in normal subjects and heart failure patients. J. Clin. Invest. 78:1362-1374.

42. Crozier, I. G., M. G. Nicholls, H. Ikram, E. A. Espiner, H. J. Gomez, and N. J. Warner. 1986. Haemodynamic effects of atrial peptide infusion in heart failure. Lancet. ii:1242-1245.

43. Braunwald, E. 1980. Pathophysiology of heart failure. In Heart Disease. A textbook of cardiovascular medicine. E. Braunwald, editor. W. B. Saunders, Philadelphia. 453-471.

44. Edwards, B. S., D. M. Ackermann, M. E. Lee, G. S. Reeder, L. E. Wold, and J. C. Burnett, Jr. 1988. Identification of atrial natriuretic factor within ventricular tissue in hamsters and humans with congestive heart failure. J. Clin. Invest. 81:82-86. 